\section{Inhibition of Astringency Removal in Semidried Japanese Persimmon Fruit by 1-methylcyclopropene Treatment}

\author{
Toshikazu Matsumoto, Hajime Matsuzaki, Kou Takata, \\ Yoko Tsurunaga, Hiroyasu Takahashi, and Takao Kurahashi \\ Shimane Agricultural Technology Center, Ashiwata 2440, Izumo, Shimane, \\ 693-0035, Japan

\section{Shinya Maki ${ }^{1}$ and Kazushi Fujiwara \\ Niihama National College of Technology, Yagumo 7-1, Niihama, Ehime, 792-8580, Japan}

Additional index words. semidried persimmon, soluble tannin, astringency removal, 1-MCP

\begin{abstract}
The inhibition of astringency removal on semidried persimmon fruit treated with 1-methylcyclopropene (1-MCP) was investigated. The rate at which soluble tannin decreased in 1-MCP-treated semidried fruit was less than control fruit, the soluble tannin concentration in dried flesh of 1-MCP-treated fruit was more than $150 \mathrm{mg} \cdot 100 \mathrm{~g}^{-1}$ on a fresh weight (FW) basis and, with sulfur treatment, reached $270 \mathrm{mg} \cdot 100 \mathrm{~g}^{-1} \mathrm{FW}$ [which exceeds the concentration of tannins required to detect astringency (Inari and Takeuchi, 2001)], and the degree of inhibition for astringency removal in semidried fruit was different among cultivars. It is suggested that these phenomena occur by the inhibition of ethylene action for fruit softening by 1-MCP treatment.
\end{abstract}

Semidried persimmon (Diospyros kaki Thunb.) is becoming a popular new type of processed fruit (Fig. 1) in Japan that is highly sought after and exported to Taipei, China. However, the procedure used for processing has some inherent problems, which include long work hours for processing and a decreased market value resulting from overproduction and the lack of efficient long-term storage (Kurahashi et al., 2005). By evenly distributing production and providing longer storage conditions for material fruit (at least 1 to 2 months), these products can yield much higher market prices. However, 'Saijo' persimmon fruit softens easily and is difficult to preserve by refrigeration more than 2 weeks after harvesting. A more effective method for material fruit storage of semidried fruit of 'Saijo' persimmon using this approach is needed. Recently, a new technology based on 1-methylcyclopropene (1-MCP), an inhibitor of ethylene perception, has become available to horticultural industries around the world. 1-MCP can delay ripening and senescence processes in many fruit and vegetables (Watkins, 2006). The effect of 1-MCP treattypes of fruits and vegetables was reported (Blankenship and Dole, 2003; Watkins, 2006). In persimmon fruit, an effect of 1-MCP was reported by Nakano et al. (2001) and Kurahashi et al. (2005). Although 1-MCP may appear advantageous for preservation of horticultural crops, no research on the effects of 1-MCP on

Received for publication 7 Mar. 2007. Accepted for publication 29 Apr. 2007

${ }^{1}$ To whom reprint requests should be addressed; ment for prolonging the shelf life for many e-mail maki@chem.niihama-nct.ac.jp. subsequent drying processing of fruit has been reported. In this study, the inhibition of astringency removal during the processing of semidried fruit treated by 1-MCP is reported.

\section{Materials and Methods}

Mature 'Saijo' fruits were harvested in the orchard of Shimane Agricultural Exper- iment Station on 15 Oct. 2005. The fruit were preclimacteric with ethylene production of $\approx 0.01 \mu \mathrm{L} \cdot \mathrm{kg}^{-1} \cdot \mathrm{h}^{-1}$ and average firmness of $2.03 \mathrm{~kg} \cdot \mathrm{cm}^{-2}$ (Fruit hardness tester KM type; Fujiwara Scientific Co., Ltd., Tokyo, Japan). The harvested fruit was prepared for following three kinds of processing materials: 1) 20 fruits $(\approx 2 \mathrm{~kg})$ were treated $1 \mathrm{mg} \cdot \mathrm{L}^{-1} 1-\mathrm{MCP}$ in an airtight container $(117 \mathrm{~L})$ at room temperature (6 to $10{ }^{\circ} \mathrm{C}$, average $7.8{ }^{\circ} \mathrm{C}$ ) for $20 \mathrm{~h}$ and stored for $5 \mathrm{~d}$ at $5{ }^{\circ} \mathrm{C}$ (1-MCP treatment); 2) 20 fruits were treated dry ice $(1.2 \%$ of fruit fresh weight) to remove astringency in fruit for $5 \mathrm{~d}$ at room temperature $\left(6\right.$ to $13{ }^{\circ} \mathrm{C}$, average $8.0^{\circ} \mathrm{C}$ ) in a sealed polyethylene bag after 1-MCP treatment (1-MCP + DI treatment); and 3) 20 fruits were stored at $5{ }^{\circ} \mathrm{C}$ for $6 \mathrm{~d}$ (control). Semidried persimmon fruit were processed as follows: 1) the removal of the pericarp by a drying period of $2 \mathrm{~d}$ (temperature 6 to $15{ }^{\circ} \mathrm{C}$, average $9.7{ }^{\circ} \mathrm{C}$, humidity $69 \%$ ); 2) a sulfur treatment in a sealed box $\left(10 \mathrm{~g} \cdot \mathrm{m}^{-3}\right.$ for $1 \mathrm{~h}$ at $\left.10{ }^{\circ} \mathrm{C}\right)$ to sterilize the surface and prevent color change of the product; and 3) machine drying started $2 \mathrm{~d}$ after peeling and continued for $7 \mathrm{~d}$. This drying machine was made with wood panels with a heat blower (Fig. 2) and the heat blower worked the interval of on (for $2 \mathrm{~h}$, temperature; up to $35^{\circ} \mathrm{C}$, humidity; up to $60 \%$ )/off (for $1 \mathrm{~h}, 15$ to $35{ }^{\circ} \mathrm{C}, 15 \%$ to $60 \%$ ). The average water content of semidried fruit was $38.1 \pm 0.4 \%$ (data not shown).

Soluble tannin content in semidried fruit during the drying procedure was detected according to Taira (1996). At each stage, the calyx and seeds were removed, cut finely, and mixed evenly. Samples (5 $\mathrm{mg}$ ) were

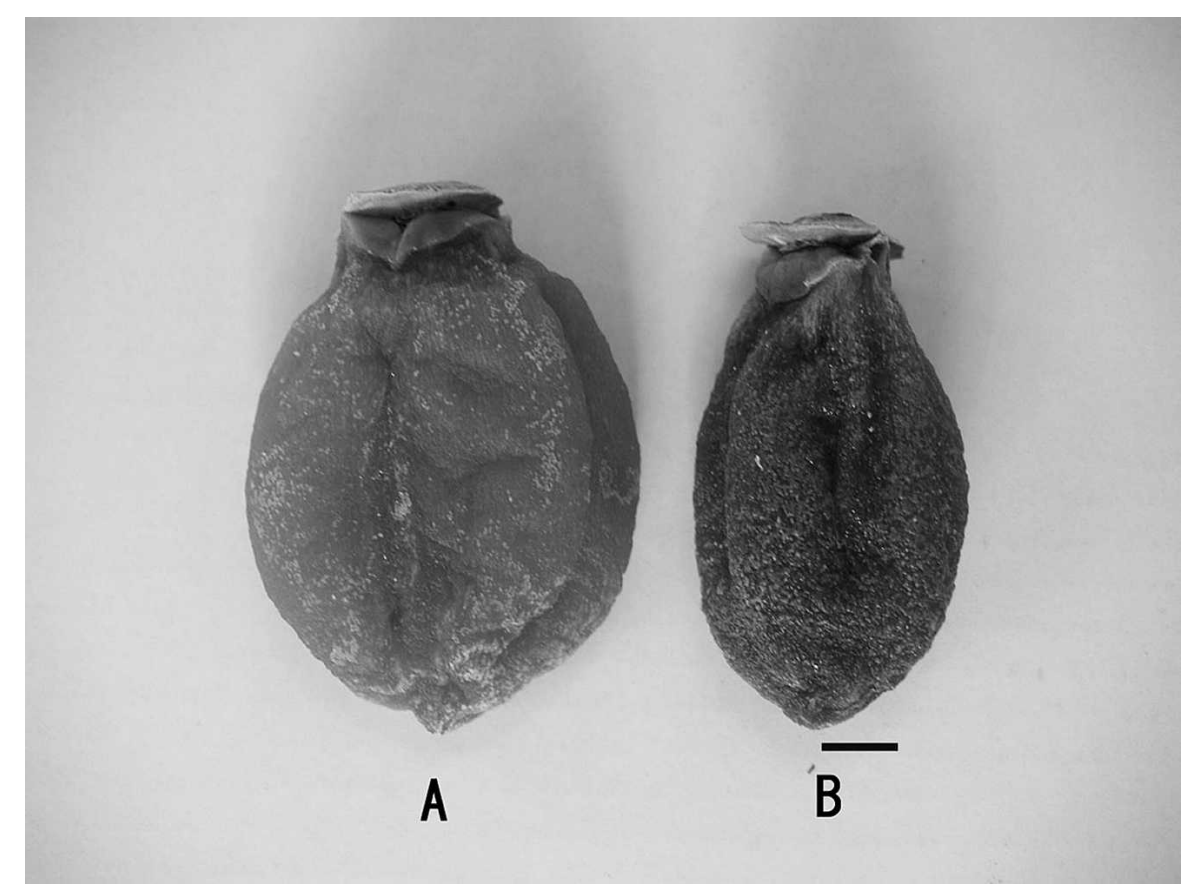

Fig. 1. Product of (A) semidried and (B) dried persimmon fruit. Bar: $10 \mathrm{~mm}$. (A) Peeled fruit was dried for $2 \mathrm{~d}$ of air drying and after $7 \mathrm{~d}$ of machine drying (water content $\approx 34 \%$ ). (B) Peeled fruit was dried for $\approx 2$ months of air drying at 5 to $15{ }^{\circ} \mathrm{C}$ (water content $\approx 15 \%$ ). 
extracted and then treated with $10 \mathrm{~mL}$ of $80 \%$ ethanol with a homogenizer (Polytron Model KR; Kineatica AG, Lucerne, Switzerland) for $\approx 10 \mathrm{~s}$. The resultant paste was then filtered and brought to $100 \mathrm{~mL}$ using an $80 \%$ ethanol solution. Ninety microliters of the solution was added to $90 \mu \mathrm{L}$ of $50 \%$ Folin-Ciocalteu Reagent (Wako Pure Chemical Industries, Ltd., Osaka, Japan) and $90 \mu \mathrm{L}$ of $10 \% \mathrm{Na}_{2} \mathrm{CO}_{3}$ solution for analysis sample. Total soluble tannin content was then detected by a microplate absorbance reader at $690 \mathrm{~nm}$ (Sunrise Thermo, TECAN, Salzburg, Austria). Standard solutions of $2,4,6,8$, and $10 \mathrm{mg} \cdot \mathrm{L}^{-1}$ were made from $(+)$-catechin hydrate (Sigma, Steinheim, Germany) for the analysis. At least three fruits were used for each analysis.

\section{Results and Discussion}

1-MCP increases the shelf life of harvested fruit and vegetables by acting as an

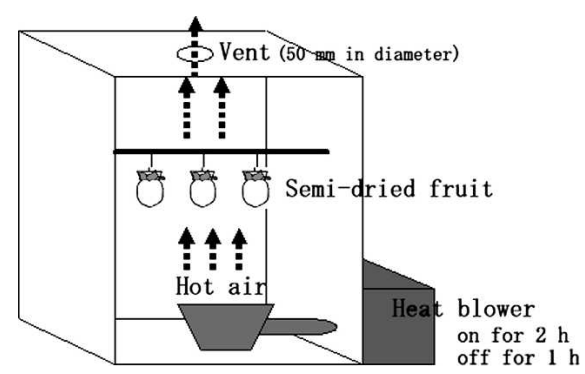

Fig. 2. A drying machine for semidried persimmon. inhibitor toward the ethylene receptors in plant tissues (Watkins, 2006).

Soluble tannin concentrations in semidried persimmon fruit treated with $1-\mathrm{MCP}$ during the drying procedure were similar to that of the untreated control by day 2 (Fig. 3), but the rate of loss in 1-MCP was subsequently much. A soluble tannin concentration of $100 \mathrm{mg} \cdot 100 \mathrm{~g} \mathrm{~g}^{-1} \mathrm{FW}$ has been reported as a threshold value to detect astringency (Inari and Takeuchi, 2001). The inhibition of astringency removal in semidried fruit treated with 1-MCP was also confirmed by a sensory test (unpublished data).

The effects of sulfur treatment before machine drying on the soluble tannin concentration in semidried fruit were tested. It was observed that a sulfur treatment tended to increase the amount of soluble tannin, especially when semidried fruit were treated with 1-MCP treated (Table 1).

The concentration of soluble tannin in semidried fruit was compared with two other cultivars of pollination-constant and nonastringent-type persimmons, 'Atago' and 'Yokono' (Table 2). The concentration of soluble tannin in 'Atago' dried fruit remained three times higher than that of 'Saijo', and a strong inhibition of astringency removal was also observed by 1-MCP treatment. On the other hand, semidried 'Yokono' fruit contained the same levels of soluble tannin between 1-MCP-treated and control samples. Inhibition of astringency removal in semidried fruit was not observed by $1-\mathrm{MCP}$ treatment (Table 2), but there was a large difference among the three cultivars in semidried fruit treated with 1-MCP.

Morphological observation on sections of 1-MCP-treated semidried fruit indicated that the flesh of 'Yokono' samples (which did not inhibit astringency) softened to the same extent as the control. However, the central flesh area of 'Saijo' samples, in which inhibition of astringency removal in semidried fruit was observed, appeared to melt, whereas most of the flesh in the 'Atago' samples (which was strongly inhibited) did not soften (Fig. 4). Electron microscopy was used to further observe the structural detail of 'Saijo' semidried fruit. Nearly all the cell walls inside the semidried fruit controls were dissolved, whereas most of the cell walls of 1-MCPtreated samples had not changed (Fig. 4).

The mechanism of inhibition for astringency removal of 1-MCP-treated material fruit appears to differ in dried and fresh fruit. Astringency occurs as a result of acetaldehyde accumulation (Pesis et al., 1988; Taira, 1996). On the other hand, Taira and Ono (1997) suggested that the reduction of astringency in dried fruit mainly occurred by two alternate factors that do not cause acetaldehyde accumulation. They are 1) by adhesion of soluble tannin to cell wall fragments produced during fruit softening (Taira and Ono, 1997), and 2) a complex formation between the soluble tannin and water-soluble pectin that increases during fruit softening (Taira et al., 1997). These mechanisms are regulated by ethylene in the flesh of the fruit (Watkins, 2006). The disassembly

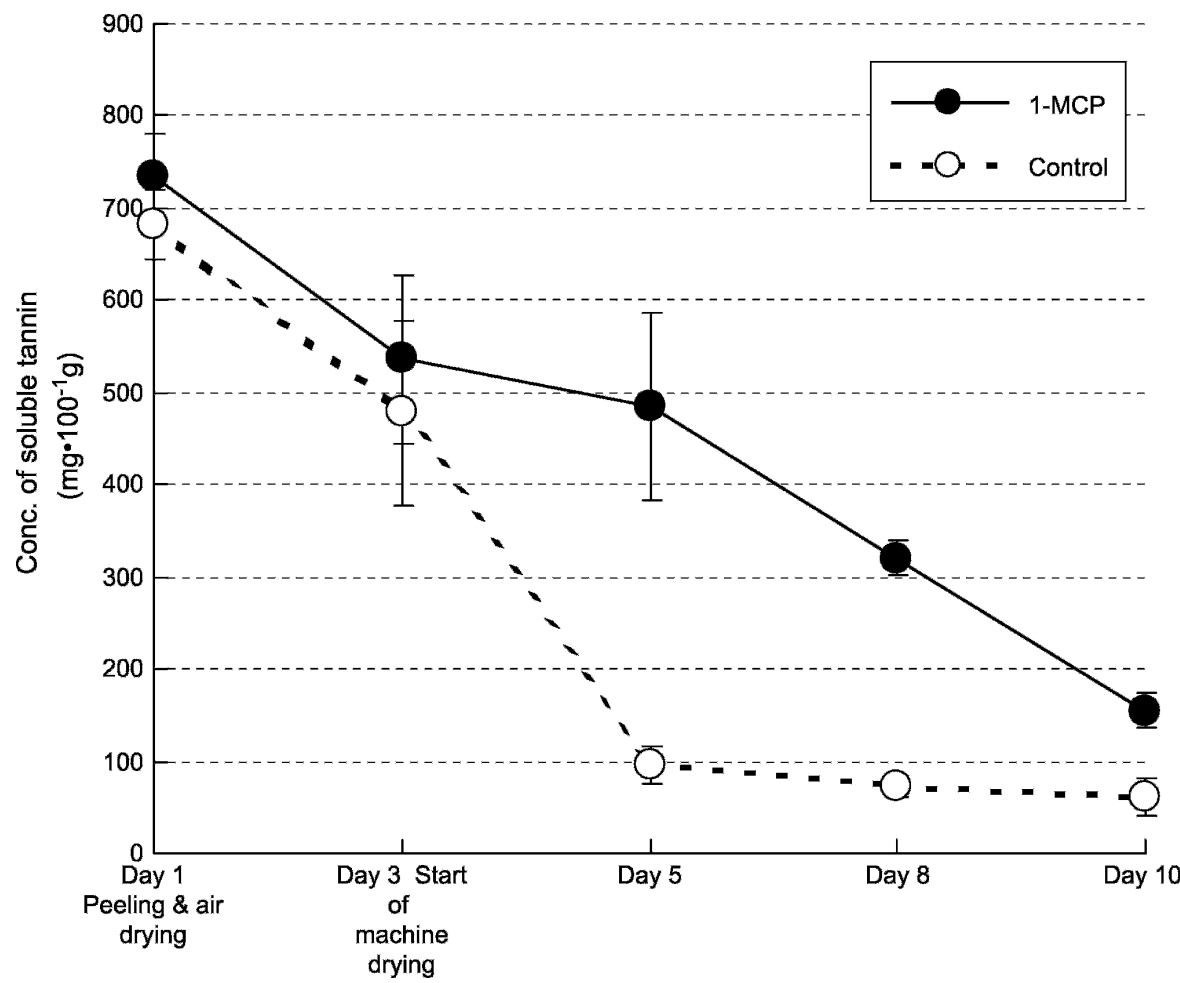

Fig. 3. Concentration of soluble tannin in semidried 'Saijo' persimmon fruit treated with 1-MCP. 1-MCP: Fruit treated with $1-\mathrm{MCP}$ at $1 \mathrm{mg} \cdot \mathrm{L}^{-1}$ for $20 \mathrm{~h}$ at $10^{\circ} \mathrm{C}$. Vertical bars represent SE. $1-\mathrm{MCP}=$ 1-methylcyclopropene.
Table 1. Effect of sulfur treatment on soluble tannin concentrations in 1-MCP-treated semidried persimmon Saijo.

\begin{tabular}{ccc}
\hline & \multicolumn{2}{c}{$\begin{array}{c}\text { Conc. of soluble } \\
\text { tannin }\left(\mathrm{mg} \cdot 100 \mathrm{~g}^{-1} \mathrm{FW}\right)\end{array}$} \\
\cline { 2 - 3 } & Nontreatment & Treatment $^{\mathrm{z}}$ \\
\hline Treatments for the material & \\
Control & $60.5 \pm 20.8(-)$ & $138.4 \pm 2.7(-)$ \\
1-MCP & $154.4 \pm 18.6( \pm)$ & $272.1 \pm 105.6(+\mathrm{y})$ \\
\hline
\end{tabular}

${ }^{\mathrm{z}}$ Sulfur $\left(10 \mathrm{~g} \cdot \mathrm{m}^{-3}\right)$ for $1 \mathrm{~h}$ after $2 \mathrm{~d}$ of peeling and air drying.

${ }^{y}$ Degree to feel bitterness $(-=$ non; $\pm=$ a little; $+=$ bitter).

Soluble tannin contents were determined afer $2 \mathrm{~d}$ of air drying and $7 \mathrm{~d}$ of machine drying.

$1-\mathrm{MCP}=1$-methylcyclopropene.

Table 2. Effect of 1-MCP treatment for materials on soluble tannin concentrations in three cutivars.

\begin{tabular}{lcc}
\hline & \multicolumn{2}{c}{$\begin{array}{c}\text { Conc. of soluble } \\
\text { tannin }\left(\mathrm{mg} \cdot 100 \mathrm{~g}^{-1} \mathrm{FW} \pm \mathrm{SE}\right)\end{array}$} \\
\cline { 2 - 3 } Cultivar & Control & 1-MCP treatment \\
\hline Atago & $95.7 \pm 19.8$ & $530.0 \pm 199.0$ \\
Yokono & $95.0 \pm 18.5$ & $95.0 \pm 8.0$ \\
Saijo & $60.5 \pm 20.8$ & $154.4 \pm 18.8$ \\
\hline
\end{tabular}

Soluble tannin conc. were determined after $2 \mathrm{~d}$ of air drying and $7 \mathrm{~d}$ of machine drying without sulfur treatment.

1-MCP = 1-methylcyclopropene. 


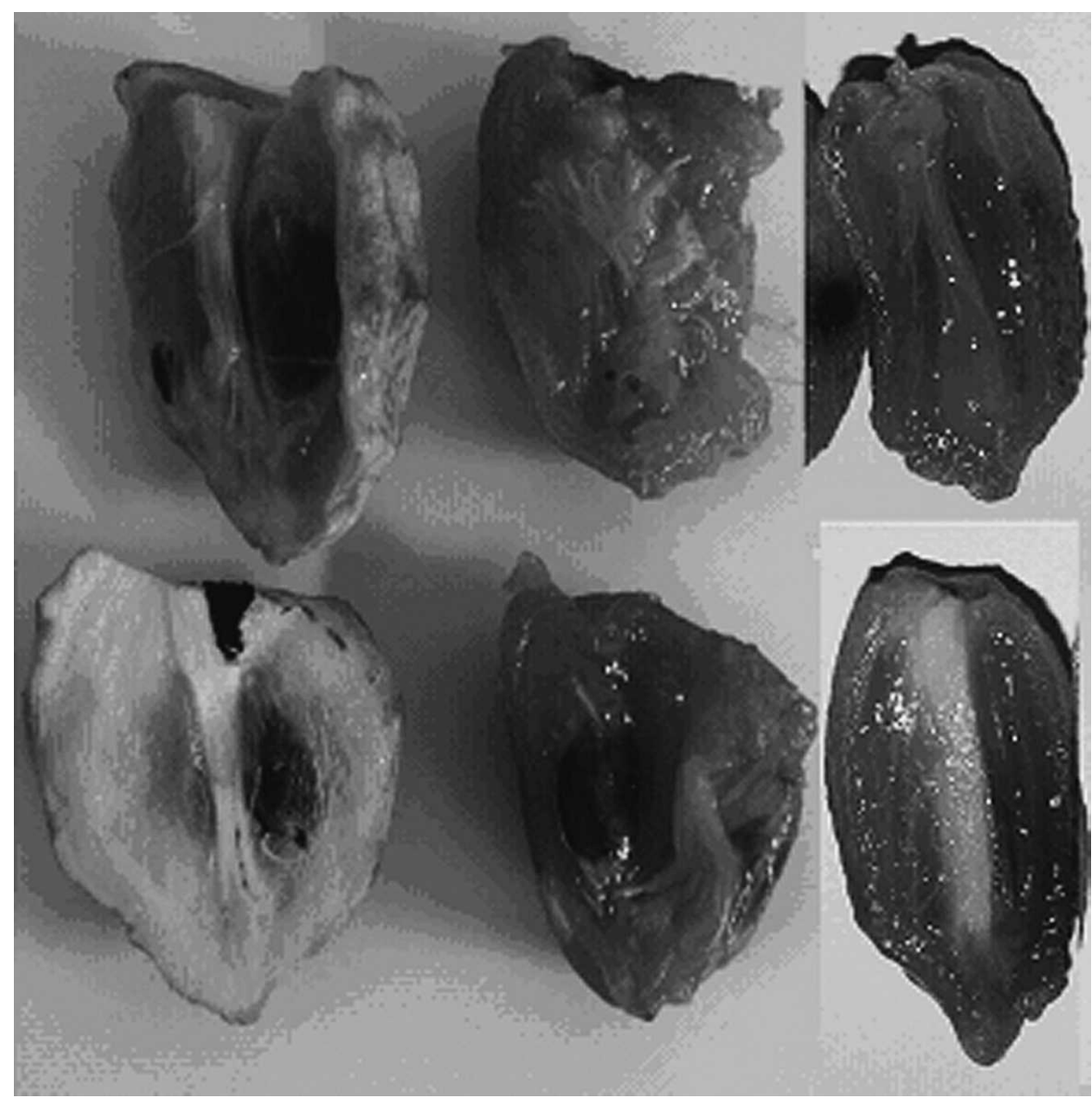

Fig. 4. Flesh of three kinds of semidried persimmon fruit treated with 1-MCP. Each fruit was peeled and then dried for $2 \mathrm{~d}$ of air drying and after $7 \mathrm{~d}$ of machine drying. Control: stored for $6 \mathrm{~d}$ at $5^{\circ} \mathrm{C}$ before peeling and drying. 1-MCP treatment: treated with $1 \mathrm{mg} \cdot \mathrm{L}^{-1}$ of $1-\mathrm{MCP}$ for $20 \mathrm{~h}$ and stored for $5 \mathrm{~d}$ at $5{ }^{\circ} \mathrm{C}$ before peeling and drying. 1-MCP $=1$-methylcyclopropene.
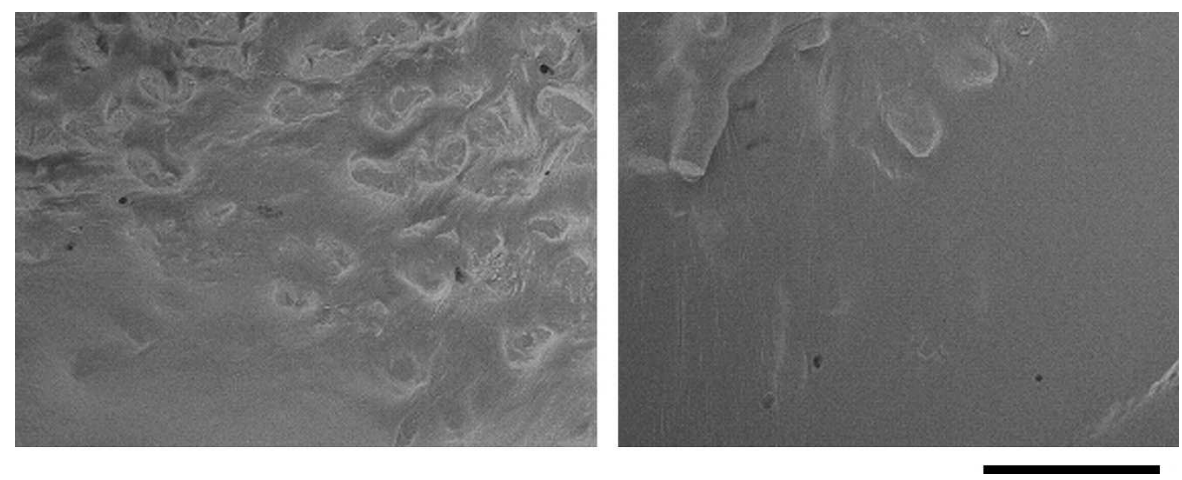

Fig. 5. Electron micrograph of semidried 'Saijo' persimmon fruit flesh treated with 1-MCP (left) and control (right). Each peeled fruit was dried for $2 \mathrm{~d}$ of air drying and after $7 \mathrm{~d}$ of machine drying. Control: stored for $6 \mathrm{~d}$ at $5{ }^{\circ} \mathrm{C}$ before peeling and drying. 1-MCP treatment: treated with $1 \mathrm{mg} \cdot \mathrm{L}^{-1} \mathrm{of} 1-\mathrm{MCP}$ for $20 \mathrm{~h}$ and stored for $5 \mathrm{~d}$ at $5{ }^{\circ} \mathrm{C}$ before peeling and drying. Bar $=0.5 \mathrm{~mm}$. 1-MCP $=1$-methylcyclopropene. and disintegration of the cell wall in 1-MCPtreated fruit during the drying procedure (Fig. 5) might be suppressed by the inhibition of the ethylene found in the fruit. In addition, the texture in 1-MCP-treated semidried fruit also decreased as a result of the inhibition of cell wall disassembly, possibly as a result of a decrease in ethylene production of the fruit. Furthermore, the different degrees of astringency removal in 1-MCP-treated semidried fruit among cultivars might depend on different sensitivity levels for these mechanisms.

In conclusion, the inhibition of astringency removal for semidried fruit was observed in some persimmon cultivars during the procedure using 1-MCP-treated material. Thus, 1-MCP treatment should be further investigated for commercial needs.

\section{Literature Cited}

Blankenship, S.M. and J.M. Dole. 2003. 1-Methylcyclopropene: A review. Postharvest Biol. Technol. 28:1-25.

Inari, T. and T. Takeuchi. 2001. The effect of the phenol substances on the pectinesterase [in Japanese]. Bul. Gifu Women's University 31: 89-92.

Kurahashi, T., T. Matsumoto, and H. Itamura 2005. Effects of 1-methylcyclopropene (1MCP) and ethylene absorbent on softening and shelf life of dry ice-treated Japanese persimmon 'Saijo' harvested at various maturation stages [in Japanese with English summary]. J. Jpn. Soc. Hort. Sci. 74:63-67.

Nakano, R., S. Harima, E. Ogura, S. Inoue, Y. Kubo, and A. Inaba. 2001. Involvement of stress-induced ethylene biosynthesis in fruit softening of 'Saijo' persimmon. J. Jpn. Soc. Hort. Sci. 70:581-585.

Pesis, E., A. Levi, and R. Ben-Arie. 1988. Role of acetaldehyde production in the removal of astringency from persimmon fruits under various modified atmospheres. J. Food Sci. 53: 153-156.

Taira, S. 1996. Astringency in persimmon, p. 97 110. In: Linskens, H.F. and J.F. Jackson (eds.). Modern methods of plant analysis. Vol. 18 Fruit analysis. Springer-Verlag, Berlin.

Taira, S. and M. Ono. 1997. Reduction of astringency in persimmon caused by adhesion of tannins to cell wall fragments. Acta Hort. 436:235-241.

Taira, S., M. Ono, and N. Matsumoto. 1997. Reduction of persimmon astringency by complex formation between pectin and tannins. Postharvest Biol. Technol. 12:265-271.

Watkins, C.B. 2006. The use of 1-methylcyclopropene (1-MCP) on fruits and vegetables. Biotechnol. Adv. 24:384-409. 